\title{
Camille Bryen Avant-Gardist/Abhumanist: A Reappraisal of an Artist Who Called Himself the "Best-Known of the Unknown"
}

\author{
Iveta Slavkova
}

check for updates

Citation: Slavkova, Iveta. 2022 Camille Bryen Avant-Gardist/ Abhumanist: A Reappraisal of an Artist Who Called Himself the "Best-Known of the Unknown". Arts 11: 43. https://doi.org/10.3390/arts 11020043

Academic Editor: John Zarobell

Received: 5 December 2021

Accepted: 1 March 2022

Published: 8 March 2022

Publisher's Note: MDPI stays neutral with regard to jurisdictional claims in published maps and institutional affiliations.

Copyright: (c) 2022 by the author. Licensee MDPI, Basel, Switzerland. This article is an open access article distributed under the terms and conditions of the Creative Commons Attribution (CC BY) license (https:// creativecommons.org/licenses/by/ $4.0 /)$.
Department of Art History and Fine Arts, The American University of Paris, 75007 Paris, France; islavkova@aup.edu

\begin{abstract}
French artist and poet Camille Bryen (1907-1977) is usually, and always very briefly, cited as a member of the post-Second World War (1939-1945) lyrical abstraction trend in Paris, often designated as Ecole de Paris or Nouvelle Ecole de Paris, Tachisme, or Informel. Bryen painted hybrids of plants, animals, rocks, and humans, mixing the organic with the inorganic, evoking cellular agglomerations, geological structures, or prehistorical drawings. He emphasized the materiality and the process through thick impasto, visible brushstrokes, and automatic drawing. Along with other abstract painters in post-war Paris, Bryen's work is usually associated with vague humanist interpretations and oversimplified existentialism. If the above statement is true for a number of his peers, it does not correspond to the way he envisaged his art, and art in general. His views are reflected in his intense theoretical reflection revolving around the term of "Abhumanism", too often completely ignored in the critical literature. Coined by his close friend, the playwright and writer Jacques Audiberti, Abhumanism claimed the inconsistency of a fallacious and pretentious humanism faced with the rawness and cruelty of recent history, and called for a revision of the humanist subject, including anthropocentrism. Both men considered art, namely painting, as a salvatory vitalist "abhumanist" act. In this paper, which is the first consistent publication on Bryen in English, I will argue that Abhumanism is essential for the understanding of the artist's work because, separating him from the School of Paris, it is, first, harmonious with his artistic production-paintings and writings; second, it clarifies Bryen's place in the history of the avant-garde, in the wake of Dada and Surrealism. This essay will contribute to the re-evaluation not only of Bryen's still underestimated œuvre, but more largely to the reappraisal of the artistic life in Paris after the Second World War.
\end{abstract}

Keywords: Abhumanism; crisis of humanism; post-World War II art; School of Paris; Jacques Audiberti; Camille Bryen; Dadaism; Surrealism

\section{Introduction}

French artist Camille Bryen (1907-1977) is usually, and always briefly, cited as a member of the lyrical post-Second World War (1939-1945) abstraction trend in Paris. In his drawings, paintings, and etchings, Bryen figured hybrids of plants and animals, and mingled the organic with the inorganic; his paintings evoke cellular agglomerations and/or geological structures, and prehistorical abstract signs. Materiality and process are emphasized through thick impasto, visible brushstrokes, and automatism. According to the traditional interpretation framework of the post-war Parisian abstraction, these formal characteristics are a mix of a dramatic existential anguish and existentialist humanism. In other words, they are a logical reaction to the horrors of the Second World War (1939-1945) and the Holocaust, but also the affirmation of the infinite faith in the spiritual capacity of humans, embodied in innovative formal propositions, to overcome such plights thanks to the power of art (De Chassey and Ramond 2008, pp. 19-32).

If this could correspond to the production of some post-war abstractionists, it certainly does not match Bryen's. First, this was not the way he himself approached his art, and art in general. Second, if we scrutinize his work in its totality-his abstract paintings, actions, 
installations, objects, photographs, poems, and objects-we will quickly understand that his rejection of any pretension toward spirituality, universalism, and humanism, and his biting critique, do not linger over anguish, even though he was probably not exempted from the syndrome of post-war anxiety. This is, at least, what his still largely understudied theoretical writings on "Abhumanism" are telling us. Elaborated together with his close friend, the playwright, writer, and occasional draughtsman Jacques Audiberti (1899-1965), who coined the term at the end of the 1940s, Abhumanism claimed that when faced with the rawness and cruelty of recent history, the lyrical humanism in art was merely fallacious. They called for a radical revision of the humanist subject, including anthropocentrism, convinced that the deflation of the humanist pretension would lead to a renewed vitalism. As we will see, Audiberti affirmed repeatedly that painting was the abhumanist activity par excellence, and that Bryen was the best example he could think of.

The historical obliteration of Abhumanism, and other "minor" trends in the post-war Parisian arts scene, has been systematic and has contributed to the canonical vision of the "decline" of Paris after the Second World War, directly linked to the narrative of the rise and fall of lyrical abstraction itself (Giroud 2008, pp. 6-8; Flahutez 2011, pp. 23-35; Slavkova 2021, pp. 90-97), and the subsequent "triumph" of American art (Dossin 2014). Bryen was somehow trapped in these narratives-one of the most popular figures of the post-war Saint-Germain-des-Prés neighborhood in Paris around the Second World War (Camille Bryen 1997, pp. 163-64), he was almost totally forgotten when the art world made a shift from abstraction to more objective art forms (Pop Art, Neo-Dada, Nouveau Réalisme, Figuration Narrative, etc.) in the 1960s. Since then, his work has remained understudied and undervalued. In currently available scholarship, this is the first consistent study on Bryen in English. ${ }^{1}$ It will approach Bryen's work through the lens of Abhumanism, connecting Bryen more largely to the history of the avant-garde (mostly Dada and also Surrealism), and pointing to the relevance of Abhumanism as a prolongation of the reflection of the avant-garde on the crisis of humanism generated by the First World War (1914-1918), and confirmed by the second world conflict. More generally, the paper will contribute to the ongoing reappraisal of the artistic life in Paris after the Second World War, assigning more attention to some understudied trends that attest to the vitality and pertinence of the European avant-garde after the catastrophe.

\section{Results: Who Is Camille Bryen?}

Given the relative oblivion of Bryen and the difficulty to find information about him in any other language than French, it is essential to provide some biographical information. Born in Nantes in 1907, Camille Briand (his real name) moved to Paris sometime in 19291930 (Camille Bryen 1997, pp. 161-65). Already known in the bohemian avant-garde poetic circles in Nantes, he settled in Montparnasse, then in Saint-Germain-des-Prés, and quickly became a well-known socialite whose company and humor were appreciated. His first one-man show took place in May 1934 at the independent Le Grenier venue in the Latin Quarter, and featured Surrealism-inspired automatic drawings. It was followed by another exhibition in 1935, showing also automatic drawings, alongside the Swedish Surrealist Erik Olson (1901-1986) at the gallery Gravitations (Figure 1). The invitation for the opening on June 18 demonstrates the strong the impact of Surrealism on both artists. Olsen's desertic dreamlike landscape with biomorphic shapes recalls Yves Tanguy; the hybrid unarticulated and highly eroticized hermaphrodite drawn by Bryen takes its cues from the Surrealist game cadavre exquis [exquisite corpse].

Before the Second World War, Bryen displayed drawings at the Salon des Surindépendants in 1935, 1936, and 1938. He associated with independent venues such as the gallery La Fenêtre ouverte (February 1937) and the bar La Cachette (March 1937), where his works were shown alongside with those of Marcel Duchamp (1887-1968) and Francis Picabia (17891953) (Camille Bryen 1997, p. 169). In 1935, Bryen's drawings were included in the first surrealist exhibition in Belgium, at the municipality of La Louvière, his first international exploit (Canonne 2012). As art historian Gaëlle Rageot has explained, his early drawings 
were purported to be destroyed but many of them reappeared in the "Bryen Fund" when it was given to the Musée des Beaux-Arts de Nantes (Rageot 1997, p. 78). Similar to the drawing reproduced on the Gravitations flyer, most of them represent incomplete, monstruous hybrids. Playing with the kingdoms of nature and subverting the hierarchy of the species, his drawings recall, as mentioned earlier, the surrealist "exquisite corpses" figures whose sections are drawn blindly by different persons resulting in disquieting, bizarre figures. Bryen worked mostly with ink and pencil on paper, an easily transportable medium that allowed him to work everywhere. In some cases, he used headed paper from bars, such as the famous Montparnasse brasserie Le Dôme in Paris (Camille Bryen 1997, p. 87). Very probably, many of his spontaneous-looking drawings were improvised in those establishments.

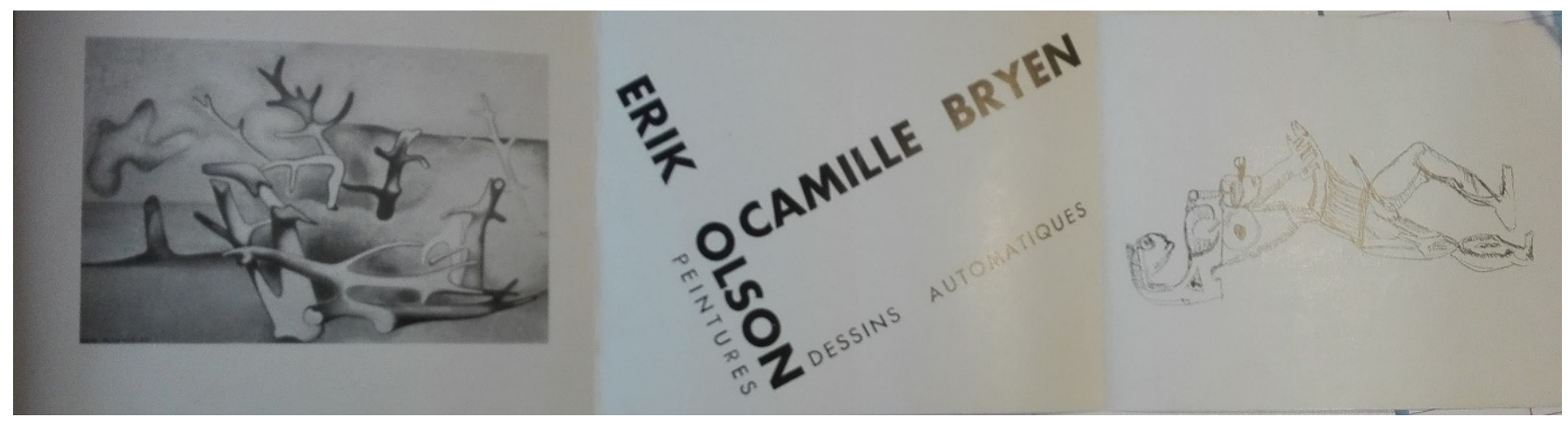

Figure 1. Invitation for the opening of the exhibition Eric Olson: Peintures/Camille Bryen: Dessins automatiques, 18 June-10 July 1935. Bryen Fund, Bibliothèque Kandinsky/Musée National d'Art Moderne/ Centre Georges Pompidou, Paris. Copyright: ADAGP.

In parallel to these Surrealism-inspired drawings, Bryen wrote poetry, made objects and artists' books, and gave extravagant conferences. For instance, on 6 April 1938, he gave a conference organized by the esoteric society "Groupe universaliste d'études traditionnelles" (Universalist group for traditional studies) with the ironic title "The occult without the occult" (Bryen Archives BRY n.d., Figure 2). In the poster, he qualified himself as an "illuminated by the Greek breasts" ${ }^{2}$, a pun on the homonymy of the French words sein (breast) and saint (saint), relating implicitly the sacred and the erotic, revealing another surrealist thread.

Bryen's best known and most ambitious projects before World War II were collaborations with the photographer Raoul Michelet (known as Ubac, 1910-1985), who was then close to the Surrealists. Their first joint project, the book Actuation poétique (Poetic Actuation), called for an "actualized" poetry interacting with life. The authors wrote that they wanted to create "poetic public actions that require the actuation of poetry" (Bryen and Michelet 1935, p. 6), and added that "the poetic activity must participate in the life of the city like an anarchistic and disturbing ferment, profoundly amoral and in a state of permanent insurrection". Their second project, L'Aventure des objets (The Adventure of the Objects, 1937), was the result of a conference Bryen gave at the Sorbonne, in which he took critical distance from the objects he had produced in the previous years (Bryen 1937). Like Marcel Duchamp's ready-mades and the surrealist objects of symbolic functioning, Bryen's assemblages made irruption into the quotidian flow, emphasizing the erotic and the marvellous potential of banal objects and places. This is evidenced in one of the book's bestknown photographs-a breast grown on a tree, offering a spoon to the spectator-which will be analyzed in more depth later (Figure 3). 


\section{LECOSMOPOLTE}

"GROUPE UNIVERSALISTE D'ÉTUDES TRADITIONNELLES'

Directeur: Claude d'YGé

Le Mercredi 6 Avril 1938

à 21 heures très précises

\section{CAMILLE BRYEN}

ÉCLAIRÉ PAR LES "SEINS GRECS"

parlera de

L'OCCULTE sans OCCULTE

"AUX GALERIES DU LiVRE"

15, Rue Gay Lussac, 15 _ PARIS Ve

Métro: Luxembourg

Participation aux frais - 4 francs

Figure 2. Poster for the conference "Camille Bryen, éclairé par les 'seins grecs', parlera de l'OCCULTE sans OCCULTE”, April 1938. Bryen Fund, Bibliothèque Kandinsky/Musée National d'Art Moderne/Centre Georges Pompidou, Paris. Copyright: ADAGP.

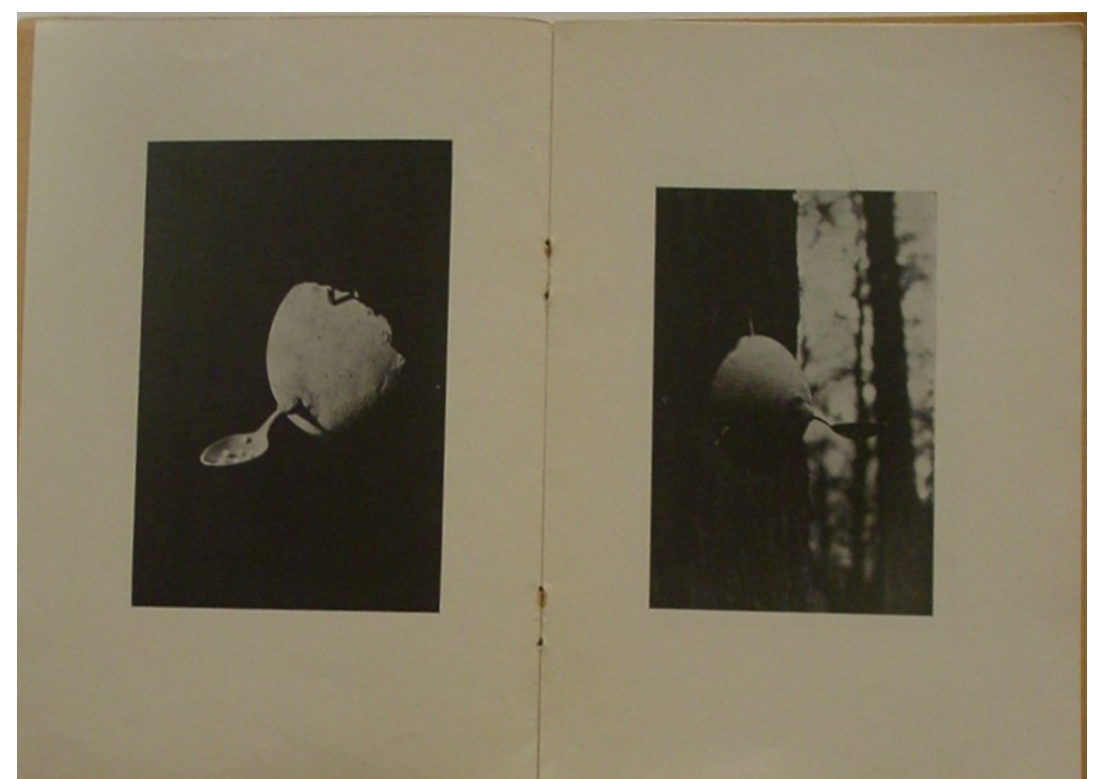

Figure 3. Camille Bryen, Le sein dans la forêt (The Breast in the Forest), 1937. Extract from the book L'Aventure des objets, Paris: José Corti, pp. 8-9. Copyright ADAGP. 
During the war years, Bryen fled Paris and his traces lead to Nantes, Bordeaux, and Lyons. He reached Marseilles where many avant-garde artists, namely a group of Surrealists, were hiding from the Vichy government; some of them, such as André Breton, Max Ernst, and Hans Bellmer, as well as his close friend Wols, applied more or less successfully for an exceptional visa for the United States through Varian Fry's Emergency Rescue Committee (Varian Fry 1999; Slavkova 2020a). Bryen returned to Paris in April 1945 and became once again one of the most popular personalities of the effervescent SaintGermain-des-Prés. A painting by the designer, architect, and filmmaker Georges Patrix (1920-1992) shows him as one of the "glories of the 6th arrondissement" next to Jean-Paul Sartre, Juliette Gréco, and Jacques Prévert (image published in Camille Bryen 1997, p. 159). Bryen is recognizable through his skinny, almost childish silhouette and his large smiling face adorned by prominent circular glasses. After the war, Bryen regularly exhibited his drawings, watercolors, and engravings and continued writing and publishing poems. He started painting with oils in 1949, producing works that intermingled the kingdoms of nature once again. Contrary to the automatic drawings from the 1930s, however, these paintings were more overtly abstract; yet, some motifs could recall insects, plants, and even humans, like in Hépérile discussed further below (Figure 4).

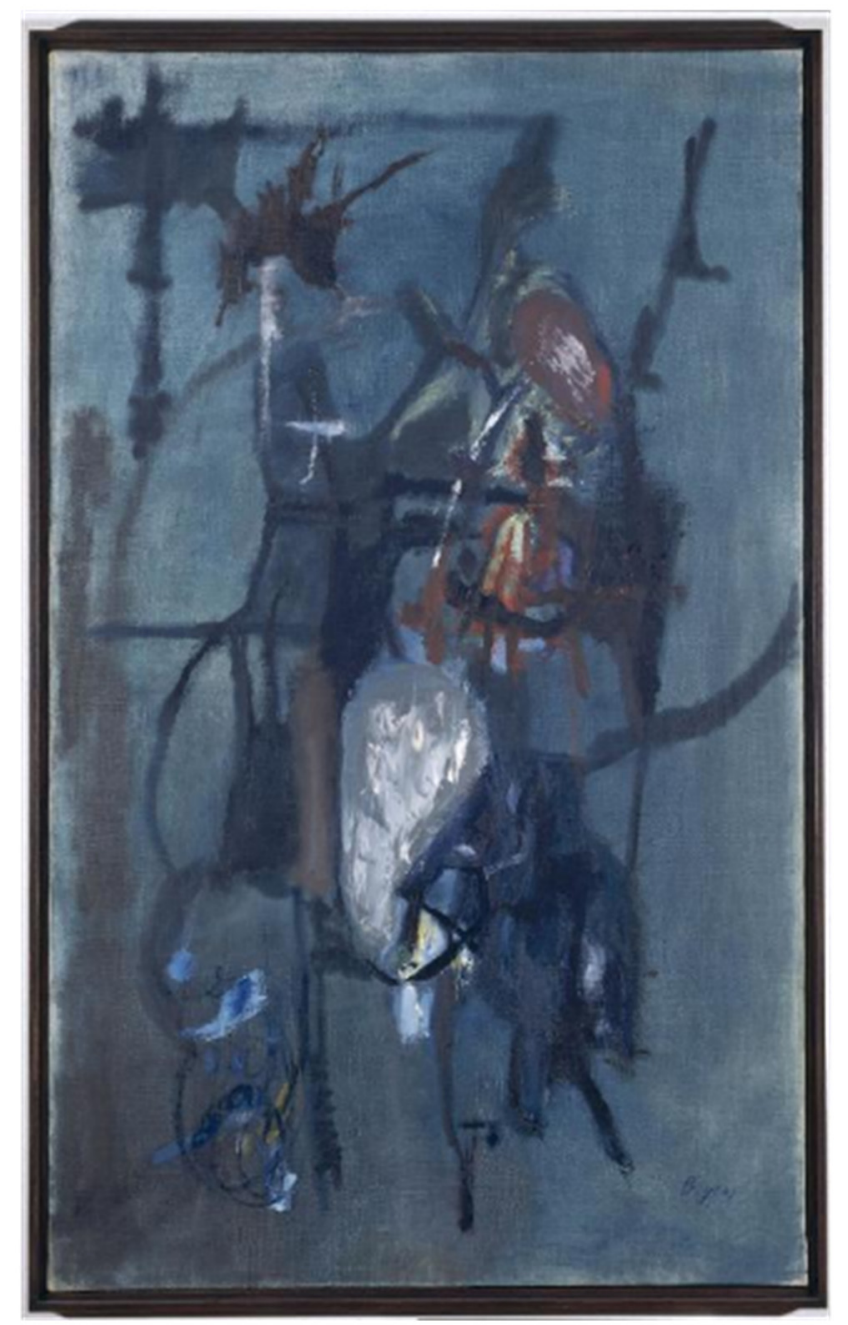

Figure 4. Camille Bryen, Hépérile, 1951. Oil on canvas, $146 \times 89 \mathrm{~cm}$. Paris, Musée National d'Art Moderne/Centre Pompidou. Copyright ADAGP.

In the decade after the Liberation of France, Bryen affirmed himself as a central figure in the Parisian avant-garde. He was, according to Michel Giroud, completely "decentralized", i.e., open-minded enough to bridge the conflicting trends coexisting in the city at the time: 
geometric and lyrical abstractionists, late Dada followers, Surrealists, Lettrists, and Zaoum sound poetry (Giroud 2008, p. 45/note 1). In the 1940s and 1950s, he took part in the epoch-making exhibitions of abstract painting in Paris: "L'Imaginaire" at the Luxembourg Gallery in December 1947, H.W.P.S.M.T.B at Collette Allendy in 1948, the now mythical "Véhémences confrontées" at Nina Dausset in 1951, which introduced Jackson Pollock to the French audience, and "Signifiants de l'Informel" organized by Michel Tapié at Studio Facchetti in 1952.

In the 1960s and 1970s, Bryen was honored by several institutional exhibitions, namely a one-man show at the Musée national d'Art moderne/Centre Pompidou in 1973 (Camille Bryen 1997, pp. 183-84). Philosopher and intellectual Umberto Eco considered his work to be a singular example of the Parisian post-war Informel (Eco 1965, p. 117). In 1976, the year before his death, Bryen was interviewed by Michel Butor for the influential among the intelligentsia French radio station "France Culture"; an innovative writer, Butor was a prominent representative of the Nouveau Roman trend. Art historian Jacqueline BoutetLoyer established the catalogue raisonné of Bryen's paintings in 1986, providing useful documentation on the works and the artist, based on archival research and conversations with Bryen and his wife Louysette (Boutet-Loyer 1986). More recently, the acquisition of Bryen's archives by the Musée des Beaux-Arts de Nantes, the dedicated work of Vincent Rousseau (former curator of this museum), and Émilie Guillard, who runs the Fondation Bryen (Bryen Foundation), led to the major retrospective Camille Bryen à revers (which could be translated as "Bryen upside down") in 1997 in Nantes (Camille Bryen 1997) and the digitalization of the archive documents accessible through the Fondation Camille Bryen/Fondation de France. ${ }^{3}$ In 2007, Guillard edited the complete writings of Bryen, published at the Presses du réel (Dijon) in the collection "L'Écart absolu" created by Michel Giroud (Bryen 2007). Despite these honors, Bryen, as he put it himself, has remained the "best-known of the unknown" (Clair 1971, p. 15).

\section{Material and Methods: Bryen and Parisian Abstraction}

Bryen is usually associated with the post-Second World War Parisian lyrical abstraction, often referred to generically as the "New School of Paris", or often shortly as the "School of Paris". It is important to define his place within Parisian abstraction because, as we will see, the context in Paris was rather conflictual and the designations could be misleading. From the late 1940s and throughout the 1950s, Bryen's work was qualified as "tachiste" or "lyrical abstraction", or yet "informel", terms associated, as mentioned above, with the rather vague School of Paris, which could be very confusing, given that there had already been quite a distinct School of Paris in the period between the wars (Adamson 2009, pp. 2-3). What was considered typical of all these abstract painters were the irregular, organic shapes, the bold gestural lines emphasizing the materiality of the pictorial surfaces. It felt natural to associate these characteristics with the state of post-war depression and the impossibility to represent the horrors of the Holocaust. But there was also a supposedly positive aspect to it-national pride. As art historian Natalie Adamson has argued, this formal language based on gestural brushstrokes, blotchy impasto-charged surfaces, freehand composition, and impassioned coloration was seen as a universal and noble poetic expression, which contributed to the restoration of the humanist values in France, and the revival of Paris as the art capital of the world (Adamson 2009, pp. 7-9). There was a kind of a "race for humanism" when art was appropriated for political purposes. The champions of abstraction, associated broadly with Gaullism, were opposed to those of Realism and figuration, linked to the French Communist Party; both claimed to be the safekeepers of the universal humanism inherent to French tradition and the Enlightenment (Adamson 2009, pp. 11, 116-17, 143-50, 172). Between the two, Bernard Dorival, an influential art historian and the first director of the newly founded Musée national d'Art moderne in Paris, affirmed that the current French art was the most valid heir to the values of Western humanist painting since the Renaissance (Dorival 1946, pp. 323-24). This idea was supported by many French intellectuals across the political spectre. A defender of traditional Catholic values, writer Georges Bernanos 
(1888-1948) declared in 1948 on the front page of the Gaullist newspaper Carrefour that "France will be tomorrow, like never before, the head and the heart of a renewed Humanity" (Bernanos 1948, p. 1). The belief that France was the homeland of humanism was not new. During the First World War, many French intellectuals had associated their country with the defence of universal humanist values against German savagery and barbarism; to them, fighting for these values could justify the necessity of the conflict and even its violence (Slavkova 2020b, pp. 77-84).

How did Bryen fit into this? Bryen was indeed one of the pioneers of lyrical abstraction in Paris, launched by the exhibition "L'Imaginaire" in 1947, first entitled "Vers 1'Abstraction lyrique" (Towards Lyrical Abstraction, Camille Bryen 1997, p. 173). Bryen initiated the show together with the gestural abstract painter Georges Mathieu (1921-2012) with the goal of countering geometrical abstraction, which they deemed too cold and dogmatic. The two men exhibited side by side with artists who would become the cornerstones of Parisian abstraction: Jean-Michel Atlan (1913-1960), Jean-Marc Riopelle (1923-2002), and Wols (Otto Wolfgang Schulze, 1913-1951). Notwithstanding, Bryen's place within the abstract scene is quite ambivalent. If we take two major figures of the period, art critic and theoretician Charles Estienne (1908-1968) and art critic, writer, and curator Michel Tapié (1919-1987), we will see that their attitude toward Bryen is rather evasive. Charles Estienne, who became the champion of Tachisme, as well as of l'Ecole de Paris, used extensively the term "lyrical abstraction", without including Bryen in the inaugural show of the New School of Paris, as he called, at the Salon d'Octobre of 1952 (Musée des Beaux-Arts and Duvillier 2011, pp. 159-60). Originating in the word "tache" [stain], "Tachisme" was an ironic designation for lyrical abstraction that Estienne appropriated to give a more specific identity to his New School of Paris (Ragon 2001, p. 63). In 1954, Estienne vaguely reproached to Bryen not to seek beauty in the act of painting, contrary to the artists he was defending (Estienne 1984, p. 9). Yet, Bryen was perceived by some, such as the influential critic and champion of lyrical abstraction Julien Alvard, as a member, or even the initiator, of the School of Paris and Tachisme (Alvard 1955, p. 12).

As for Michel Tapié, he did include Bryen in his book Un art autre, the manifesto of what was referred to as "Informel" (Tapié 1994). For many exegetes, Bryen was the father of Informel. Thus, in his book L'Art informel, the influential critic and writer, and director of the Nouvelle Revue Française, Jean Paulhan (1884-1968), stated that "Informel" was invented in homage to Bryen (Paulhan 1962, p. 20). Bryen specialist Jacqueline Boutet-Kapéta confirms that the definition of Informel has been frequently used in relation with the artist, and that the formal qualities of his art match this trend (Boutet-Kapéta 1997, pp. 109-110). However, the definition of Infomel is broad and vague, ranging from Jean Dubuffet (1901-1989) and Hans Hartung (1904-1989) to Etienne-Martin (1913-1995) and Victor Brauner (1903-1966). If Tapié emphasized the role of Jean Dubuffet or Georges Mathieu, he mentioned Bryen only twice, and quite briefly: first, in relation to the exhibition "Signifiants de l'Informel" in 1952, and second, in comparison with Hartung and Wols (Tapié 1994, np). Two early paintings-Hépérile (1951, Figure 4) and Tellurie (1952, Figure 5) are reproduced in Un art autre.

Despite the relative vagueness of Tapié's theory, his emphasis on Nietzschean impulse, on the rawness and inhumanity of art (the book opens on this affirmation) stood against the lyrical outpourings of his contemporaries, which were impregnated with even vaguer humanism (Tapié 1994, unpaginated). The hostilities, quarrels, and often artificial frontiers between the different Parisian abstract or semi-abstract trends at the time were notorious: if these groups were united in their fight against geometric abstraction and figuration, they nonetheless attacked each other viciously whenever the opportunity arose (Adamson 2009, pp. 163-204). 


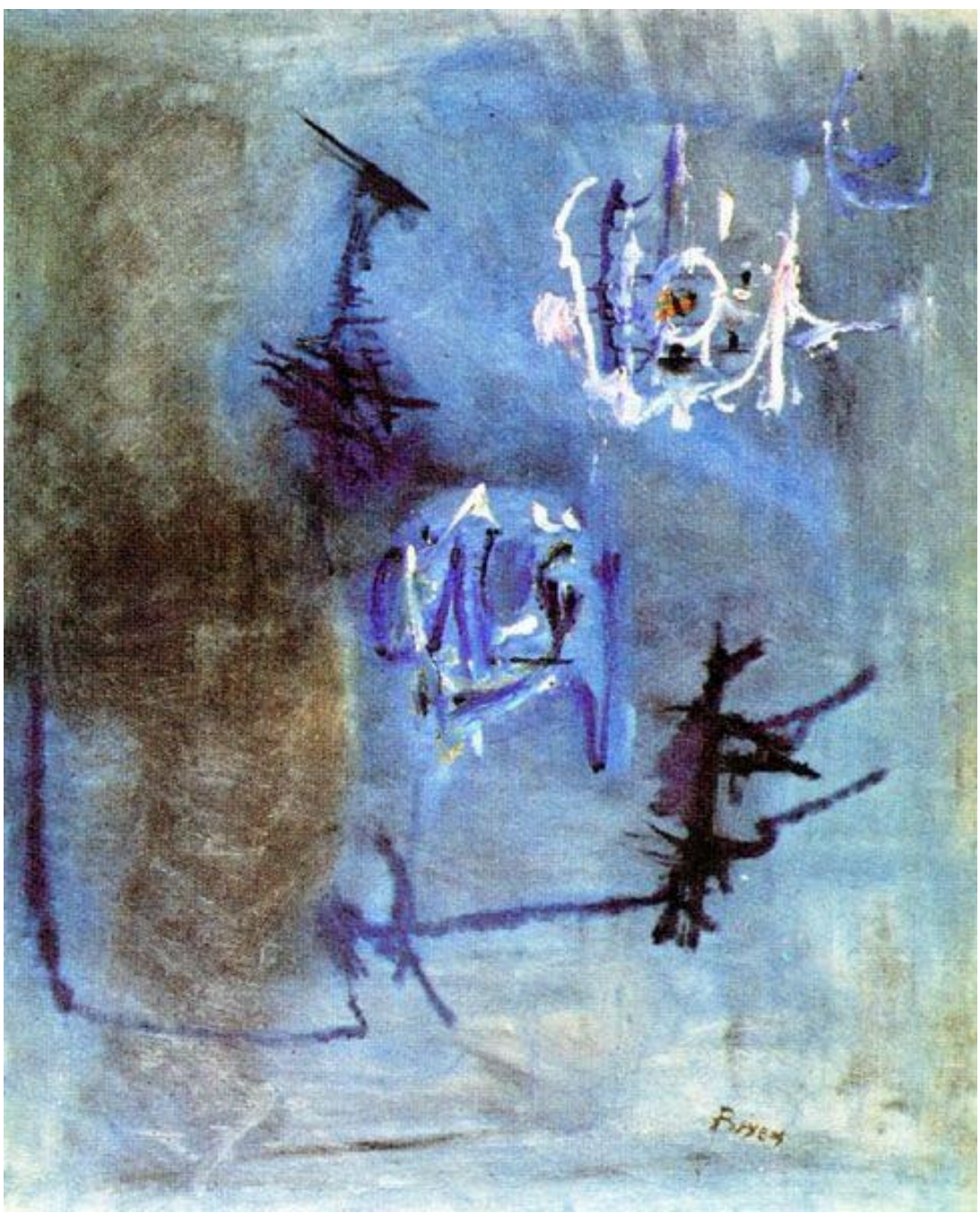

Figure 5. Camille Bryen, Tellurie, 1952. Oil on canvas, $100 \times 81 \mathrm{~cm}$. Nantes, Musée des Beaux-Arts. Copyright: ADAGP.

Limiting Bryen's art to any of these tendencies is pointless. In one of the rare in-depth studies on Parisian abstraction in English, Natalie Adamson mentions Bryen only three time (Adamson 2009, pp. 174, 181, 191), virtually excluding him, and rightfully so, from the scope of the Ecole de Paris. The relative impossibility of classifying him is confirmed by other art historians. In her book Après la guerre, for instance, Laurence Bertrand-Dorléac mentions briefly Bryen as a Neo-dadaist (Bertrand-Dorléac 2010, p. 65). On the other hand, Fabrice Flahutez points to the close relationship between Bryen and phonetic poetry circles around Iliazd, Ilia Zdanevich (1894-1975) (Flahutez 2011, pp. 106-8, 161-63). As we have seen, according to Michel Giroud, Bryen is, along with Marcel Duchamp, Hans Arp (1866-1986), Antonin Artaud (1896-1948), and Jean Dubuffet, one of the "transformative singularities who didn't want to impose themselves as a model" (Giroud 2008, p. 6). Giroud also emphasizes the various collaborations between Bryen and all kinds of artists, namely the future Nouveaux Réalistes Raymond Hains (1926-2005), Jacques Villeglé (b. 1926), and François Dufrêne (1930-1982) (Giroud, 45/note $1^{4}$ ). It is then unsurprising that Pierre Restany, the founder and theoretician of the Nouveau Réalisme movement-which rejects lyrical abstraction and shares some characteristics with Pop Art-was one of Bryen's

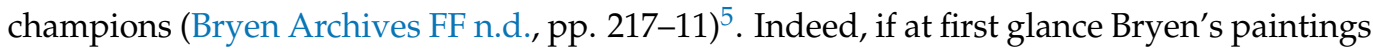
fit formally in lyrical abstraction, the totality of his production does not. In Bryen abhomme, Daniel Abadie even hesitated to call Bryen an abstract painter and labelled him viveur du réel (one who lives the real), stressing the material presence of his œuvre (Abadie 1973, p. 15). 
He stated that, unlike the dominant discourse on abstraction, Bryen's work is determined by the urgency of making; the forms produced are a décantation du réel (distillation of the real) rejecting the poeticization or the mythologization of the act of painting (Abadie 1973, p. 8).

\section{Discussion}

\subsection{The Rejection of Humanism, from Dada to Abhumanism}

As outlined above, despite the great number of enthusiastic testimonies, Bryen has remained a confidential figure in the canonical post-war intellectual and artistic history because of the relative depreciation of the Ecole de Paris-or more largely the sense of exhaustion and inactuality of post-war Parisian abstraction caused by the arrival of more objective-biased figuration-orientated movements such as New Realism and Nouvelle Figuration, who took a critical stance toward consumerism-but also because of the underacknowledgement of the diversity of his production in the literature on the period. The relation of Bryen's work with Dada and Surrealism is one axis that needs more attention. We have discussed aspects of his connection to Surrealism through the practice of automatic drawing and personal acquaintances (Ubac), but more needs to be done. The artist had a strong affinity with Dada. He claimed so himself (Camille Bryen 1997, pp. 59-61, 182), and Michel Giroud insisted on this connection in his analysis of Bryen's works from the 1930s, specifically in L'Aventure des objets (Giroud 1997, pp. 59-61). Indeed, the incongruous objects photographed by Ubac stand somewhere between Dada and Surrealism, evoking desire and the unconscious; they are dreamlike but ironic and distant at the same time. Like the Surrealists, Bryen sought to liberate desire, to explore the "instinctual menagerie" where human actions arise (Bryen 1937, p. 17). Like the Dadaists, he left the raw process visible, loved the biting and unforgiving irony, and cherished the ugly, the clumsy, and the low.

"Le Sein de la forêt" (The Breast of the Forest) that Bryen hung in the forest of Meudon near Paris corresponds to the above description. His acolyte Ubac took a picture of it, which was published in L'Aventure des objets (Bryen 1937, pp. 8-9, Figure 4). The page dedicated to the visual in the book highlights the object's inception: Bryen had a dream about a plaster breast, an object he was working on at the time, hanging in the forest; the tree was a metaphor of the individual — or the male; it could be read as both-whereas the forest stood for society; the spoon covered with white bulging excrescences referred to the ovum and to ovarian production (Bryen 1937, p. 10). Globally, the object is an allusion to desire seen simultaneously as a spiritual and bodily mechanism. Desire is the result of the intertwining of mental fantasies and bodily fluids; it provokes exaltation and repulsion. A short poem and explanatory note sent by Bryen to his friend Jacques Audiberti in 1939 discusses another anthropomorphic eroticized tree with breasts (Audiberti Archives n.d., 593DBT 106.1). Here, Bryen narrates another dream of a forest that mysteriously leads to an encounter with a woman with whom he falls in love for just one marvellous night; after her departure, she sends him a photo of herself as a prisoner of an anthropomorphic tree. Eventually, Bryen concludes that "this text implies the existence of a psyche connecting the tree as a male element to the female, which [ . . . ] could be considered as an expression of poetic life" (Audiberti Archives n.d., 593 DBT 106.1).

The convergence of this object with Surrealism is obvious: the importance given to dreams and their interpretation; the estrangement of the everyday environment; and the allusion to a violent erotic scene in the Marquis de Sade's Justine ou Les Malheurs de la vertu where the trees play an important role (de Sade 1993, pp. 89-92), a scene that Bryen cited in both the above-cited archive document and in L'Aventure des objets (Bryen 1937, pp. 8-9; Audiberti Archives n.d., 593DBT 106.1). Additionally, it is similar to Marcel Duchamp's subsequent book cover for the exhibition catalogue "Surrealism in 1947", in which a bulging breast invites the reader to touch (Prière de toucher, Please touch, $1947^{6}$ ). Whether Duchamp was inspired from "Le Sein dans la forêt" is unknown, but it is clear that Bryen was inspired by Duchamp's ready-mades, which, according to him, transformed the "reflection on art 
into art" (Bryen and Butor 1994, p. 412). Bryen believed in the Dadaist notions of antiart and art as life. In this sense, he considered Duchamp, whom he knew quite well, more as a Dadaist than a Surrealist; he affirmed that Dada, contrary to Surrealism, did not seek to make art but to enlarge the very conception of art (Bryen and Butor 1994, p. 410).

The Dada connection brings us back to Tapié and Informel. In the very first pages of Un art autre, Tapié insisted that Dada and Nietzsche were the greatest revolutionaries of modern times and that Informel was indebted to them because it was opposed to humanism (Tapié 1994, np). To Tapié, the artwork was something inherently inhuman, expressing "the most vertiginous endeavour that man must confront" (Tapié 1994, np). Tapié didn't clarify what the essence of Dada's inspiring antihumanism was; his aim was to implicitly oppose the humanist claims assumed by other abstract trends in Paris. However, his statement that the Dadaists, in the wake of Nietzsche, were the most virulent critics of humanism during and after the First World War (1914-1918) is quite insightful. Indeed, many Dadaists, across Europe and beyond, considered the conflict as evidence of the "perverse effects" of the humanist paradigm established in Western culture since the Renaissance (Slavkova 2020b, pp. 30-34, 363). The Dadaists put their finger on the aporias of rationality, they analyzed critically the relationship of humanity with its environment, and they shattered the rational and linear definition of subjectivity and the self. Rejecting anthropocentrism and positivism, they approached dialectically the notions of technology and progress (Gaughan artin Ignatius 2006) and conceived visual representation of the hybridity and instability of the self, among other ways, through their reflection on the cyborg, a hint to a new non-humanist subjectivity (Biro 2009, pp. 127-30; Slavkova 2020b, pp. 363-72). After the Great War, Man could be considered neither as the most beautiful and intelligent creature in the universe, nor as the warrant of the cosmic order. The painter Francis Picabiaa cosmopolitan Dadaist circulating between New York, Paris, and Barcelona-discarded the ideals that made possible the massacre of so many young men; to him, those ideals were dead with the war: "you die like a hero or like an idiot, it's all the same" ${ }^{\prime 7}$ (Picabia 1920). After the Second World War, the French Dadaist of German descent Hans Arp wrote in "Dadaland" that the humanist worldview was responsible for the megalomania that precipitated humanity into the furious folly of two self-destructive industrial massacres (Arp 1985, pp. 306-9).

Bryen knew both Arp and Picabia and collaborated with them on several occasions (Bryen and Butor 1994, p. 410; Giroud 1997, p. 61). He shared their poor opinion of humanity and humanism to the point that in 1952 he co-authored with playwright Jacques Audiberti a book-manifesto against humanism: L'Ouvre-boite. Colloque abhumaniste (The Can Opener. Abhumanist colloquium, Audiberti and Bryen 1952). Through a punchy dialogue full of ironic puns and anecdotes, in the wake of Arp, Picabia, and other Dadaists, the authors denounced the piteous state of a humanity who has engendered two world wars within a quarter of a century in the heart of civilized Europe. They invited the reader to ponder human presumptuousness, and to analyze critically, the insufficiencies of Western civilization and its founding principle since the Renaissance-humanism. The term "Abhumanism" included the Latin prefix - $a b$, meaning "far from, or separation", explicitly inviting humanity to break up with humanism. Shortly after L'Ouvre-boite, Audiberti published another volume, L'Abhumanisme where he defined as Abhumanists other creators: the anarchist Bakounine (Audiberti 1955, pp. 155-56), the actor/director Charlie Chaplin (114), and the writer Victor Hugo (80-94). Even though Abhumanism was not an actual movement, it prolonged the goal of the historical avant-garde to redefine the role of literature and art in society, especially after the disillusionment and the horror of the world wars and the Holocaust. Audiberti and Bryen's attack on humanism was more concretely geared toward Sartre's exclamatory humanism-existentialism, as well as the humanist pathos surrounding abstraction at the time (Slavkova 2021, p. 87). 


\subsection{Why Is Abhumanism Key to Understanding and Revalorizing Bryen?}

As Michel Giroud wrote, the rupture with humanism is essential to understanding the role that Bryen played as a "discreet" but outstanding "relay" of the Dada spirit in Paris between the wars, and just after World War II (Giroud 1997, p. 59). Pierre Restany also underlined the importance of Bryen's rejection of humanism and often referred to it (Restany 2015, pp. 52-53). Besides, the painter Georges Mathieu, a major figure of post-war lyrical abstraction in Paris, and a friend and admirer of Bryen, briefly discussed Abhumanism in his book Désormais seul en face de Dieu (Henceforth Alone Before God; Mathieu 1998, pp. 162-63). Interrogating the possible influence of Abhumanism on Wols, whom he held in the highest esteem, Mathieu agreed with Bryen's argument that humanism was a potentially totalitarian paradigm imposing an abstract and perfect human being (162). However, Giroud, Restany, and Mathieu, as well as the previously mentioned Abadie (Abadie 1973, pp. 26-28), are exceptions in the critical fortune of Abhumanism. Charles Estienne and Michel Tapié ignored completely Bryen's adherence to Abhumanism, even though Informel explicitly opposed the vague humanism of the School of Paris. In general, in the historiography of both Bryen and Audiberti, the scope of Abhumanism has been constantly undermined. To give just one example, Jean-Yves Guérin, the expert on Audiberti in France, dismissed Abhumanism as a vague philosophical divagation made up by two otherwise talented creators, a fashionable fad to which Audiberti yielded at one point, only to give it up at the end of his life (Guérin 2015, pp. 25-27).

It is beyond doubt that Bryen claimed his attachment and fidelity to Abhumanism until the end of his life. In the summer of 1971, in an interview with the art critic Jean Clair, he said that he was an Abhumanist, opposed to the humanist artists and scientists who are convinced that art and science "translate reality" (Clair 1971, p. 14). According to Bryen, reality was impossible to define, much less to "translate". A year before he died, in his conversation with Michel Butor, the artist expressed his surprise that Abhumanism was completely ignored in the then raging intellectual debate around structuralism and post-structuralism (Bryen and Butor 1977, p. 32) ${ }^{8}$. He added further that he did not take part in the discussion because he was not a philosopher, but he had the feeling that Audiberti and himself had contributed to this discussion. Bryen also emphasized the importance of Abhumanism to art. One of his best-known poems, "Jepeinsje" (Bryen 2007, pp. 189-91), is an ode to the act of creation as an abhumanist act. The title is a neologism contracting the French verbs penser [think] and peindre [paint], playing on the identical pronunciation of $j e[\mathrm{I}]$ and jeu [game]. Bryen clearly suggests a direct connection between brain and hand, body and mind - "to paint" and "to think" are one and the same. Through the recurring shift in personal pronouns, the poem also affirms the multiplicity of an immanent subjectivity where the physical and the spiritual, the subject and the environment are indistinct, countering anthropocentrism and linear subjectivity as postulated by the humanist tradition:

"You ochre I cavern you troglodyte

I abhumanize to abhumanium

I insect we masticate I fry stones" ${ }^{\prime \prime}$ (190)

Bryen invites us to "abhumanize" until we lose ourselves in the "abhumanium" and start "insecting", which may imply adopting the perspective of an insect and giving up our exclusively human stance. The above-mentioned painting, Hépérile (Figure 5), could illustrate this strophe. Displayed for the first time at the landmark exhibition, "Véhémences confrontées" (Paris, Nina Dausset Gallery, 8-31 mars 1951), this is one of the first oil paintings Bryen produced. The title comes from a phonetic poem written in 1950 (Bryen 2007 , p. 129). The black gestural lines allude to a hybrid being, an insect-plant, a sort of a paradoxical living fossil—a fossil because of the strong linearity suggesting a thin skeletal structure; a living organism because of the dynamic diagonals and the stains of blood-like red paint laid in fleshy impasto. The form reminds one of a fly, with two red bulging eyes and black tentacles; or a quadruped covered —why not?-with patches of white wool as 
suggested by the rapid thick vertical white strokes; or-another hypothesis—a gathering of figures inspired by prehistorical drawings of humans; or, maybe, all these at the same time. It is true that the free "circulation" between the species and the natural kingdoms is a recurring topos in abstraction. Yet Bryen's approach has something insistingly material and raw, even awkward, that Abadie called "the distillation of the real" (Abadie 1973, p. 8). Instead of a nostalgic yearning for a universal harmony through universal shapes, his undefined forms are motivated by a desire to escape anthropomorphism and humanism, to refute the belief that the felicitous linear rational progress of humanity would lead to a perfect human-dominated cosmos, a universal happiness guaranteed by the wisdom of mankind and the beauty of art. Bryen's radical rejection of this point makes no doubt: "There is no reason that the economy of the universe should be subdued to our human investigations" (Audiberti and Bryen 1952, p. 41).

According to Audiberti, this exactly constituted the abhumanist essence of Bryen's art. In "Camille Bryen poileur de pierres", written on the occasion of the painter's one-man show at the Galerie des Deux-Îles in the Spring of 1949, Audiberti insisted on the distance separating Bryen from humanist painting, his rupture with his kind, and his absolute lack of interest in human aspirations. Closer to fungi and viruses, his oil paintings (like Hépérile), drawings, and watercolours are the expression of a raw, cruel, and inhuman poetry. Bryen's work, Audiberti wrote, "grows like mildew. It develops little by little on the white sheet, like a fungal growth. Ah! Such a beautiful bronchitis! [ . . ] His fried stones (pierres poilées) are indigestible, they don't go in the universal bag that made up Dante or the Pantheon (Audiberti 1973, p. 121). Audiberti concluded that Bryen's art was a contemporary form of sorcery resulting in a magic formula for modesty.

Audiberti's title gave the untranslatable expression poileur des pierre [stone fryer] used by Bryen in Jepeinsje: "I insect we masticate I fry stones" (Bryen 2007, p. 190). Bryen thus appropriated Audiberti's implicit criticism of the vanity of utilitarian rational activities: poiler evokes the word poil or hair, so the "stone fryer" may also be someone who "puts hair on stones" or "grows hair on stones"; obviously, frying/growing hair on stones is equally nonsensical and counterproductive. Audiberti also alluded to the unsuspected transformative qualities of matter-stones become flesh-a topic Bryen cherished. Moreover, the phrase may refer to prehistory since the neologism poiler is an anagram of the verb polir or polish, so poileur de pierre is implicitly linked with the polishing of stones, the first creative act of the prehistoric humans that we know. In his poem, Bryen related "abhumanizing" to ochre painting, which, juxtaposed with "cavern" and "troglodyte", recalls the prehistoric humans' painting materials and techniques. Bryen was fascinated with the abhumanist quality of prehistory, when vulnerable humans had to adapt to their unpredictable environment (Slavkova 2021, pp. 89-90).

\section{Conclusions}

For Audiberti and Bryen, the visual arts, and painting in particular, had a special role to play in the deconstruction of humanism. In an open letter to Audiberti dated 1951, Bryen wrote: "Above all, it is important to note that one would understand nothing of the current art if one does not take into consideration Abhumanism" (Bryen 2007, p. 411). In L'Abhumanisme, Audiberti defined painting as an "abhumanist hypothesis" because of the impossibility to fix a repertory or a code of all the effects it was susceptible to deploy (Audiberti 1955, p. 70). Bryen's painting was mentioned in the first pages of L'Ouvre-boite as the point of departure of the abhumanist colloquium:

"The need to discuss the work of Bryen sparked the cumulative dialogues that form this book. Taking cues from the possibility to validly insert his canvases, which look like they were made by langoustines, anemones, ants..., into a network of sociological relationships stretching from paint merchants to gallery directors, we felt obliged to attempt to highlight the human which resides in the inhuman, as a kind of a revanche." (Audiberti and Bryen 1952, p. 28) 
Sprouting from the depth of bodily and spiritual matter, impossible to control, art was a kind of anti-humanist Trojan horse; the revanche of the non-human for all the harm brought by the pretentious humanist humans, the proof of their unsoundable depth and undefinable self. Approaching creation as a sort of eco-ontology, Bryen suggested that, if we do not hierarchize the Mona Lisa, a dog's dream, or a thought by a chrysanthemum (Alvard 1955), the act of painting was a glimpse into a new, more equitable, though not so reassuring, cosmic order.

Funding: Different institutions have supported this project at different stages of its elaboration. In 2012, a research grant from the lab HiCSA at Paris I Panthéon-Sorbonne in 2012 funded my research on Bryen's archives in Nantes. The same year, a travel grant from the HAR lab at the Universite de Paris Nanterre supported my participation at the EAM conference "Material Meanings" at the University of Kent. The paper presented there provided the backbone of this article. More recently, a Faculty Development Grant from the American University of Paris (AUP) enabled me to work on Jacques Audiberti's archive at the IMEC in Caen, where autographs by Bryen are conserved. Another AUP grant made possible the copyright payment for the images published here.

Acknowledgments: I express my gratitude to Marie-Louise Audiberti, Jacques Audiberti's daughter, who authorized me to fully access her father's archive. I also thank Vincent Rousseau, the former chief curator of the Musée des Beaux-Arts in Nantes for his help on the archive work. My gratitude goes also to Fabrice Flahutez from the Université de Lyon-Saint-Etienne who has supported and encouraged this research project, his advice and guidance in the exploration of this period are inestimable. My colleague Bernard Zirnheld has provided precious help with the English translation of Audiberti's and Bryen's texts as well as insightful remarks on Abhumanism.

Conflicts of Interest: The author declares no conflict of interest.

\section{Notes}

$1 \quad$ A translation in English of some poems and text extracts was published in 2017, translated by John Doherty (Bryen 2017). I wrote a short article in English for the Gazette Drouot in 2021 (https:/ / www.gazette-drouot.com/article/camille-bryen-the-forgottenglory-of-saint-germain-des-pres/28430, accessed on 12 May 2021).

2 All translations are mine unless otherwise stated.

The Foundation Camille Bryen is managed by the Fondation de France; the digitalized archives are accessible via the website http:/ / camillebryen.fr/base-documentaire, accessed on 22 February 2022.

4 This lengthy footnote is almost one page long and mentions Bryen's collaboration with diverse artists: Picabia, Duchamp, Iliazd, Wols, Hains, Villeglé, and Dufrêne.

5 Tapuscript of a conversation between Bryen and Restany entitled: "Dialogue abhumaniste entre Pierre Restany et Camille Bryen", dated 1957.

6 Marcel Duchamp, Prière de toucher, 1947. Mixed media, cover for the exhibit catalogue "Surrealism in 1947 ", $41.8 \times 34.7 \times 7.1 \mathrm{~cm}$. Paris, MNAM/Centre Pompidou (https:/ / www.centrepompidou.fr/fr/ressources/oeuvre/cBKoXpz, accessed on 30 November 2021).

7 In French, héros and idiot rhyme, so the sentence sounds like a proverb: "On meurt en héros ou en idiot, ce qui est la même chose."

8 The conversations between Bryen and Butor were broadcast on the French national radio France-Culture the week of 9 April 1976. Bryen and Butor $(1994,1977)$ have published transcriptions of different parts of this long interview.

9 Here is the original text in French: “Tu ocres je caverne tu troglodytes/j'abhumanise à l'abhumanium/j'insecte nous mastiquons je poile de pierre."

\section{References}

Abadie, Daniel. 1973. Bryen, Abhomme. Brussels: La Connaissance.

Adamson, Natalie. 2009. Painting, Politics and the Struggle for the Ecole de Paris. London: Routledge.

Alvard, Julien. 1955. Bryen. Cimaise, October/November. p. 12.

Arp, Hans. 1985. Jours Effeuillés. Poèmes, Essais, Souvenirs 1920-1965. Paris: Gallimard.

Audiberti Archives. n.d. Fund Jacques Audiberti. 593DBT. Correspondence and texts by Camille Bryen: 593DBT 106.1. Caen: IMEC.

Audiberti, Jacques. 1955. L'Abhumanisme. Paris: Gallimard.

Audiberti, Jacques. 1973. Camille Bryen poileur de pierre. In Bryen Abhomme. Brussels: La Connaissance, pp. 118-121.

Audiberti, Jacques, and Camille Bryen. 1952. L'Ouvre-boîte. Colloque Abhumaniste. Paris: Callimard.

Bernanos, Georges. 1948. La plus grande escroquerie de l'Histoire. Carrefour 5: 1. Available online: https://www.retronews.fr/journal/ carrefour-la-semaine-en-france-et-dans-le-monde/07-janvier-1948/1685/3105077/1 (accessed on 1 December 2021). 
Bertrand-Dorléac, Laurence. 2010. Après la Guerre. Paris: Gallimard.

Biro, Matthew. 2009. The Dada Cyborg: Visions of the New Human in Weimar Berlin. Minneapolis: University of Minnesota Press.

Boutet-Kapéta, Jacqueline. 1997. Camille Bryen, peintre informel. In Camille Bryen à Revers. Nantes and Paris: Musée des Beaux-Arts de

Nantes and Somogy, pp. 109-115.

Boutet-Loyer, Jacqueline. 1986. Camille Bryen. L'œuvre peint. Paris: Librairie des Quatre Chemins.

Bryen Archives BRY. n.d. Fund Camille Bryen. Paris: Bibliothèque Kandinsky and Musée national d'Art modern.

Bryen Archives FF. n.d. Fund Camille Bryen. Nantes and Paris: Musée des Beaux-Arts de Nantes and Fondation de France.

Bryen, Camille. 1937. L'Aventure des Objets (Conférence Prononcée à la Sorbonne, Paris, le 3 mai 1937). Paris: José Corti.

Bryen, Camille. 2007. Désécritures. Poèmes, Essais, Inédits, Entretiens. Edited by Michel Giroud and Émilie Guillard. Dijon: Presses du réel.

Bryen, Camille. 2017. Camille Bryen, paroles d'artiste. Edited by John Doherty. Translated by John Doherty. Lyon: Fage Editions.

Bryen, Camille, and Michel Butor. 1977. Michel Butor interroge Camille Bryen. L'Ouvre-Boîte (Cahiers Jacques Audiberti) 7: 27-35.

Bryen, Camille, and Michel Butor. 1994. Un rêve océanique. In Le Rêve d'une ville. Nantes et le surréalisme. Nantes and Paris: Musée des Beaux-Arts de Nantes and RMN, pp. 405-413.

Bryen, Camille, and Raoul (Ubac) Michelet. 1935. Actuation Poétique. Paris: René Debresse.

Camille Bryen à revers. 1997. Nantes and Paris: Musée des Beaux-Arts de Nantes/Somogy.

Canonne, Xavier. 2012. Le Surréalisme à La Louvière: Un Abécédaire du Surréalisme dans les Collections de la Province de Hainaut. La Louvière: Centre de la gravure et de la ville de La Louvière.

Clair, Jean. 1971. Propos d'un abhumaniste. Art vivant 22: 15.

De Chassey, Eric, and Sylvie Ramond. 2008. Repartir à zéro. Comme si la Peinture n'avait Jamais Existé. Lyon and Paris: Musée des Beaux-arts and Hazan.

de Sade, Marquis. 1993. Justine ou Les malheurs de la vertue. Paris: Le Grand Livre du mois.

Dorival, Bernard. 1946. Les Étapes de la Peinture Française Contemporaine. Pepuis le Cubisme, 1911-1944. Paris: Gallimard, vol. 3.

Dossin, Catherine. 2014. To Drip or to Pop? The European Triumph of American Art. Artl@s Bulletin 3: 80-103.

Eco, Umberto. 1965. L'CEuvre Ouverte. Paris: Seuil.

Estienne, Charles. 1984. D'un style en germination (preface for the exhibition Corneille at Colette Allendy Gallery, March 1954). In L'Art à Paris, 1945-1966. Paris: Centre national des Arts Plastiques, p. 9.

Flahutez, Fabrice. 2011. Le Lettrisme historique était une avant-garde. Dijon: Presses du réel.

Gaughan artin Ignatius. 2006. The Prosthetic Body in early Modernism: Dada's Antihumanist Humanism. In Dada Culture. Avant-Garde Critical Studies. Edited by Dafydd John. Leiden: Brill, vol. 18, pp. 138-152.

Giroud, Michel. 1997. Miniatures papillon [ . . . ] Je suis un décadenassé, Camille Bryen inventeur de la poésie naturelle. In Camille Bryen à revers. Nantes and Paris: Musée des Beaux-Arts de Nantes and Somogy, pp. 57-67.

Giroud, Michel. 2008. Paris, Laboratoire des Avant-Gardes: Transformations-Transformateurs, 1945-1965. Dijon: Les Presses du réel.

Guérin, Jeanyves. 2015. Dictionnaire Audiberti. Paris: Honoré Champion.

Mathieu, Georges. 1998. Désormais seul en face de Dieu. Genève: Âge d'Homme.

Musée des Beaux-Arts, and Marc Duvillier. 2011. Charles Estienne, critique d'art des années 1950. L'Aventure de l'art abstrait. Brest: Musée des Beaux-Arts de Brest.

Paulhan, Jean. 1962. L'Art informel. Paris: Gallimard.

Picabia, Francis. 1920. Le Manifeste cannibale dans l'obscurité. DADAphone (Dada). In 1976. DADA, Réimpression Intégrale et Dossier Critique de la Revue Publiée de 1916 à 1922 par Tristan Tzara. Edited by Michel Sanouillet. London: NICE, p. 213.

Rageot, Gaëlle. 1997. L'Éclatement et la métamorphose dans l'œuvre graphique de Camille Bryen. In Camille Bryen à revers. Nantes and Paris: Musée des Beaux-Arts de Nantes and Somogy, pp. 77-93.

Ragon, Michel. 2001. 50 Ans d'art vivant. Paris: Fayard.

Restany, Pierre. 2015. Abhumanistement vôtre. In Camille Bryen. Le passant outre. Paris: Galerie Thessa Herold, pp. $52-53$.

Slavkova, Iveta. 2020a. Cemetery=Civilization: Circus Wols, World War II and the collapse of humanism. Arts 9: 93. [CrossRef]

Slavkova, Iveta. 2020b. Réparer l'homme. La Crise de l'humanisme et l'Homme nouveau des avant-gardes Autour de la Grande Guerre (1909-1929). Dijon: Presses du Réel.

Slavkova, Iveta. 2021. The Strange Destiny of Wols, the "French Pollock". Reflections on Abhumanism and the Parisian Avant-garde in Periphery after World War II. Revista da Història da Arté 9: 83-97.

Tapié, Michel. 1994. Un art autre. Paris: Artcurial.

Varian Fry et les candidats à l'exil, Marseille 1940-1941. 1999. Arles: Actes Sud. 